\title{
Seed transmission of Sarocladium oryzae and Fusarium moniliforme in different genotypes of rice
}

\section{RAJBIR SINGH* AND KARUNA VISHUNAVAT ${ }^{1}$}

Department of Plant Pathology, Gochar Mahavidyalaya, Rampur Maniharan, SAHARANPUR (U.P.) INDIA

${ }^{1}$ Department of Plant Pathology, G.B. Pant University of Agriculture and Technology, Pantnagar, U.S. NAGAR (UTTRAKHAND) INDIA

\section{ARITCLE INFO}

Received : 09.07 .2015

Accepted : 30.09 .2015

\section{KEY WORDS :}

Seed transmission, Sarocladium oryzae, Fusarium moniliforme

*Corresponding author:

Email: rajbirsingh2810@gmail.com
How to view point the article : Singh, Rajbir and Vishunavat, Karuna (2015). Seed transmission of Sarocladium oryzae and Fusarium moniliforme in different genotypes of rice. Internat. J. Plant Protec., 8(2) : 397-399. 